\title{
Jaringan dan Sistem Sosial dalam Distribusi Komoditas Pertanian Lahan Kering
}

\author{
Fadly Husain, ${ }^{1}$ Gunawan, ${ }^{2}$ Thriwaty Arsal ${ }^{3}$ Asma Luthfi, ${ }^{4}$ Hartati Sulistyo Rini ${ }^{5}$ \\ Program Studi Sosiologi dan Antropologi Fakultas Ilmu Sosial Universitas Negeri Semarang \\ (e-mail: 1fadlyhusain@mail.unnes.ac.id; 2goenantro@mail.unnes.ac.id; \\ 3thriwaty_arsal@mail.unnes.ac.id; ${ }^{4}$ asma.luthfi@gmail.com; \\ 6hartatisulistyorini@mail.unnes.ac.id)
}

\begin{abstract}
Farming systems in the highlands have special typologies, as the development of dryland farming systems in the form of "tegalan" or gardens. This farming system also exists in several regions in Central Java. The aim of the study is to understand the distribution network system of local commodities (coffee, cocoa, and sugar palm at the local level). This study used qualitative research methods. The subjects in this study were the community (farmers) in Medono Village, Boja District, Kendal Regency. The results showed that the coffee and palm sugar distribution network system is carried out by collectors who come from local people and vendors or entrepreneurs from outside the village.
\end{abstract}

Sistem bercocok tanam di wilayah dataran tinggi memiliki tipologi yang khas, yaitu berkembangnya sistem pertanian lahan kering yang berupa tegalan atau kebun termasuk di beberapa daerah di Jawa Tengah. Penelitian ini ingin memahami jaringan dan sistem distribusi komoditaskomoditas lokal (kopi, coklat, dan aren di tingkat local). Penelitian ini menggunakan metode penelitian kualitatif. Subjek dalam penelitian ini adalah masyarakat (petani/pengelola) di Desa Medono Kecamatan Boja Kabupaten Kendal. Hasil penelitian menunjukkan bahwa jaringan dan sistem disribusi komoditas kopi dan aren dilakukan dengan memanfaatkan pengepul dari orang lokal dan penadah atau juragan dari orang luar.

Keywords: aren; agro-economy; land characteristics; coffee; dry land plantations 


\section{Pendahuluan}

Sistem bercocok tanam di wilayah dataran tinggi memiliki tipologi yang khas. Di wilayah tersebut berkembang pertanian lahan kering berupa tegalan atau kebun. Sistem pertanian lahan kering berkembang di pegunungan atau dataran tinggi serta tempat-tempat tertentu lainnya tersebut dikarenakan faktor keterbatasan ketersediaan air dan tanpa adanya sistem irigasi teknis (Abdurrahman, Dariah, dan Mulyani 2008; Prasetyo dan Suriadikarta 2006).

Lahan pertanian tegalan memiliki sifat umum, yaitu rentan terhadap erosi, tingginya penurunan tingkat kesuburan, serta tidak dapat dikerjakan secara intensif. Hal itu sangat berbeda dengan sistem pertanian sawah. Jenis tanaman yang dibudidayakan di lahan kering juga sangat berbeda dengan tanaman yang dikembangkan di lahan pertanian sawah. Lahanlahan kering umumnya digarap untuk menanam tanaman palawija, seperti jagung, dan ketela. Meskipun padi juga ditanam namun produktivitasnya rendah. Suryanata (1999) mencatat bahwa pemanfaatan lahan kering di wilayah dataran tinggi di Jawa mengalami perubahan formasi yang signifikan. Lahanlahan kering yang semula digarap untuk produksi pangan, mulai bergeser pemanfaatannya dengan ditanami tanaman-tanaman komoditas pasar seperti cengkeh, coklat, kopi, dan buah-buahan. Pada wilayah dataran tinggi dengan curah hujan yang rendah, lahan dimanfaatkan untuk menanam tanaman kayu seperti jati, mahoni, dan akasia. Pada wilayah dataran tinggi dengan curah hujan tinggi pemanfaatan lahan lebih variatif, dengan jenis tanaman hortikultura seperti sayur dan buahbuahan.

Luas areal pertanian lahan kering di Jawa Tengah jumlahnya cukup tinggi yaitu 738.271 ha (Kementerian Pertanian 2014). Salah satu wilayah dataran tinggi yang memiliki potensi pengelolaan lahan kering adalah Desa Medono, Kecamatan Boja, Kabupaten Kendal, Jawa Tengah. Lahan kering dikelola dengan sistem perkebunan dengan jenis tanaman berupa kopi, coklat, dan aren. Janis tanaman tersebut merupakan jenis tanaman tahunan. Selain ditanali tanaman tahunan, lahan yang relatif rata dan dekat dengan pemukiman dimanfaatkan untuk ditanami tanaman pangan seperti padi ladang, jagung.

Pengelolaan lahan kering di dataran tinggi yang dilakukan oleh masyarakat Desa Medono menarik untuk dikaji lebih lanjut dari beberapa aspek diantaranya mengenai tataguna lahan, jaringan produksi dan distribusi kamoditas yang dihasilkan, serta bentuk-bentuk sistem sosial yang terbentuk oleh pengelolaan hasil kebun berupa kopi, dan aren. Berdasarkan uraian di atas maka penelitian ini bertujuan untuk menjelaskan: 1) karakteristik pengelolaan lahan perkebunan pada Masyarakat Medono dan 2) Sistem jaringan distribusi komoditas-komoditas lokal yakni kopi dan aren.

Data dalam artikel ini diperoleh dengan menggunakan metode kualitatif. Adapun subjek dalam penelitian ini adalah masyarakat di 
Desa Medono Kecamatan Boja Kabupaten Kendal khsususnya petani yang memiliki lahan dengan tanaman kopi dan petani penderes.

\section{Pertanian Lahan Kering dan Agrikultur}

Ruiter (1999) melakukan kajian tentang perkebunan karet di Desa Bukit Bangun di dataran Tinggi Kabupaten Langkat, Sumatera Utara. Di dalam dinamika aktivitas perkebunan ini aspek lingkungan tanah dikaitkan dengan aspek tenaga kerja, dan aspek produksi yang merupakan proses penting dalam pembentukan masyarakat tani Karo. Bukit Bangun dijadikan jendela masuk guna menggambarkan diferensiasi pertanian dan perubahan pada tingkat lokal. Sebagaimana dijelaskan oleh White (1999) bahwa diferensiasi pertanian adalah proses perubahan yang terus berlangsung, ketika berbagai kelompok dalam masyarakat pedesaan, dan mereka yang berada di luarnya, mendapatkan akses atas produk-produk yang mereka hasilkan sendiri atau yang dihasilkan oleh orang lain, berdasarkan diferensiasi penguasaan terhadap sumber produksi. Kasus di Bukit Bangun, sejak tahun 1950-an muncul bentuk baru diferensiasi yang berkaitan dengan lahan. Produksi menjadi padat modal, karena pupuk dipakai untuk cengkeh dan kopi varitas unggul. Tanah dan tenaga kerja menjadi komoditas, meskipun terbatas.

Pada kasus yang berbeda yaitu tentang struktur kerja juga dapat diketengahkan di sini. Menurut Syahrizal (2006), stuktur kerja masyarakat perkebunan teh PT Mitra Kerinci di Sumatera Barat adalah sebagai berikut. Site manajer bertugas memimpin pengolahan ke- bun mulai dari penanaman sampai menjual hasil produksi. Site manajer membawahi pembantu utama yang terdiri atas tiga strata, yaitu Asisten Kepala, Kepala Dinas Pengolahan dan Teknik, dan Kepala Tata Usaha. Asisten kepala bertugas mengawasi hal-hal yang berkaitan dengan tanaman mulai dari penanaman, pemeliharaan dan pemetikan. Kepala dinas pengolahan dan teknik bertugas pada pengolahan teh yang telah dipetik sampai siap dijual. Sedangkan kepala tata usaha bertugas di bidang administrasi.

Pertanian lahan kering banyak dijumpai di dataran tinggi. Jika ditelusuri dari garis evolusionernya, pertanian merupakan perkembangan lanjutan dari zaman neolitik sebagai akibat dinamika interakasi manusia dengan lingkungan (Hutterer 1984). Begitupun dengan pertanian lahan kering, sistem ini merupakan komponen penting yang berkembang pada akhir masa prehistoris. Di Beberapa tempat seperti di Hawaii (Ladefoged, Graves, dan Jennings 1996), intensifikasi pertanian lahan kering merupakan salah satu kegiatan utama yang dilakukan oleh masyarakat sejak dulu hingga sekarang. Di sana, dikenal 3 (tiga) sistem pertanian lahan kering utama yakni Kohala, Kona, dan Leimia Lalamilo. Sistem Kohala merupakan sistem pertanian lahan kering khas di Hawaii karena dilakukan dengan membuka lahan seluas 19 x $4 \mathrm{~km}$ di lereng kering Pegunungan Kohala yang bidang lahannya menghadap arah angin. Adapun komoditas yang dihasilkan dari sistem pertanian lahan kering ini diantaranya kentang, talas, ubi, pisang, tebu, sukun, dan murbei yang ditanam ditepi lading atau di ketinggian. Ketiga 
sistem pertanian lahan kering di Hawaaii dapat dilihat sebagai perkembangan lanjut dari sistem pertanian prehistori yang dihasilkan dari proses adaptasi, ekspansi, dan intensifikasi. Proses adaptasi dilakukan dengan diperkenalkannya tanaman baru dan budidaya baru yang disesuaikan dengan karatkteristik dan kondisi lokal, ekspansi dilakuakn dengan memperluas area pertanian dengan pola pertanian yang telah mapan, serta intensifikasi dilakukan dengan meningkatkan input (seperti bibit dan pupuk) untuk memperoleh hasil pertanian yang maksimal. Dengan model pertanian lahan kering ini, masyarakat Hawaii dapat memanfaatkan lahan kering mereka untuk pemenuhan kebutuhan pangan masyarakat.

Selain sebagai sistem mata pencaharian, pertanian juga dapat menjadi mekanisme keamanan dan ketahanan pangan dalam kondisi laju pertumbuhan penduduk yang ekstrim. Di Kenya Barat, terdapat sistem pertanian Hamisi yang dilakukan dengan pola pertanian yang intensif dan penerapan agro diversity (Conelly dan Chaiken 2000). Dalam hal ini, agro diversity dapat dimaknai sebagai proses seleksi alam yang intensif dan mengintegrasikan pertanian, peternakan, dan nelayan di suatu wilayah pertanian. Petani terlibat dalam pola pertanian yang menggunakan beberapa varietas tanaman, model tumpang sari, tanaman yang memiliki banyak fungsi, dan integrasi tanaman dan ternak. Hanya saja, kerawanan pangan masih menjadi ancaman yang serius di Kenya Barat sebab tekanan penduduk yang tinggi yang mengakibatkan lahan pertanian menjadi semakin sempit. Di samping itu, pemenuhan gizi keluarga, utamanya protein masih sangat terbatas dan bergantung pada suplay pasar.

\section{Komoditas Lokal}

Dalam penelitiannya, Smith (2010) memberikan gambaran signifikan bagaimana pengelolaan komoditas lokal kopi rakyat Honduras yang semula menggunakan pola-pola konvensional dan tunduk pada perdagangan global, lantas beralih pada pilihan untuk mengakomodir model fair trade yang memberikan perhatian pada kesejahteraan petani dan pertanian yang berkelanjutan melalui organisasi Copan Cooperativa. Murray (Smith 2010) menyatakan bahwa fair trade menjadi gerakan sosial dan berbasis pada pendekatan pasar untuk mewujudkan pengembangan yang berkelanjutan dalam hubungan antara produsen dan konsumen. Dalam konteks ini, Smith (2010) menegaskan bahwa dengan fair trade, mekanisme alternatif ini menjadi alat untuk mengentaskan kemiskinan, melakukan bisnis yang transparan dan akuntabel, perwujudan dari demokrasi, pembangunan dan penguatan kapasitas masyarakat, harga yang adil, serta memiliki fokus pada persoalan lingkungan.

Dalam implementasi fair trade, menurut Smith (2010) terdapat beberapa aspek penting yang dapat dilihat sebagai bukti atas komitmen alternatif pasar ini untuk memperhatikan aspek berkeadilan antara produsen dan konsumen, yaitu: pertama, sertifikasi, terdapat standar-standar penilaian terhadap komoditi yang diperjualbelikan, dan selalu diadakan penilaian terhadap standar yang telah ditetapkan tersebut. Kedua, dapat ditelusuri, produk yang diperjualbelikan harus dapat ditelusuri 
dan memiliki bukti yang otentik melalui dokumen tertentu. Produk-produk ini, harus terpisah dan dapat diidentifikasi tersendiri dari produk non-fair trade. Ketiga, kontrak, terdapat kontrak yang saling menguntungkan antar penjual dan pembeli terkait dengan kualitas yang diharapkan, harga, banyaknya jumlah komoditas, pola pembayaran dan kondisi pengiriman. Keempat, perdagangan berkelanjutan, menyediakan akses jangka panjang bagi penjual dan pembeli untuk melihat hal-hal yang dilakukan dalam proses produksi diantaranya: rencana produksi, pembagian informasi, harga terkini, pelatihan dalam masa produksi. Kelima, pembiayaan, memberikan akses pada produsen terhadap bentuk-bentuk pendampingan pada pembiayaan, yang disepakati dengan kepentingan yang rendah dan kemampuan produsen untuk meminta kenaikan sampai $60 \%$ atau lebih berdasarkan nilai kontrak sesuai dengan kesepakatan para pihak, dan keenam adalah penetapan harga, harga minimal dalam fair trade adalah nilai awal untuk negosiasi harga dan pembeli harus membayar sesuai dengan produk beserta premi khusus sebagai tambahan.

Smith (2010) menegaskan kembali bahwa fair trade (perdagangan yang berkeadilan) terbukti menjadi strategi pengembangan ekonomi alternatif yang akan dapat terus berjalan untuk Copan Cooperativa. Fair trade tampaknya membantu kelompok-kelompok tertentu seperti Cooperativa Copan memasuki pasar kopi global yang lebih baik, dan tersedianya informasi tentang proses perdagangan yang dapat terpantau dimana perdagangan konvensional tidak mampu melakukannya. Bahwa petani masih menghadapi kendala seperti biaya sertifikasi dan masuk ke dalam fair trade, namun model ini terus berkembang untuk memperbaiki jaringan bagi produen di seluruh dunia. Penekanan fair trade juga telah bergeser, karena bukan hanya menekankan pada tujuan pengembangan masyarakat lokal dan keadilam sosial, namun juga mengarah pada perdagangan yang melibatkan perusahaan transasional. Dalam hal ini, peran pemerintah juga diharapkan lebih signifikan lagi dalam melakukan reformasi kebijakan baik pemerintah lokal, maupun institusi bilateral dan multilateral, terkait dengan pembiayaan dan dukungan implementatif yang mampu mendukung keberlanjutan produksi kopi pada negara-negara penghasil kopi tersebut.

Eakin dkk. (2006) menyatakan bahwa adaptasi petani yang dilakukan untuk merespon terjadinya krisis kopi di Mexico, Guatemala, dan Honduras terkait dengan eksistensi dan pengembangan jaringan petani lokal, serta pelayanan penyedia dan informasi sumber daya. Hal ini menjadi penting dalam konteks liberalisasi ekonomi dan pertanian global. Petani Honduras menjadi petani yang paling adaptif dan pro aktif menanggapi situasi ini. Berbagai faktor yang muncul untuk menunjang kapasitas adaptasi pada tiap negara diantaranya adalah akses pada pasar dan informasi teknis di dalamnya, dan pembiayaan dan kepemilikan lahan yang cukup untuk diversifikasi pertanian dengan tanaman alternatif juga menjadi sangat penting. Selain itu, perbedaan dalam akses teknologi pertanian dan pelayanannya juga terkait dengan solusi yang dihasilkan. 
Fromm dan Dubón (2006) menganalisis mengenai dampak kebijakan pemerintah lokal dan produsen terhadap jatuhnya harga kopi internasional dalam 15 tahun terakhir pada petani berskala kecil di Honduras. Program yang diciptakan untuk membantu petani kopi skala kecil beradaptasi terhadap perubahan pada pasar global dan melakukan pendampingan terhadap peningkatan daya saing mereka. Inisiatif ini termasuk penerapan standar kualitas, identifikasi pembeli langsung untuk memastikan keuntungan yang lebih tinggi, dan sertifikasi yang menunjukkan keaslian produk. Hasilnya, kebanyakan produsen telah terlibat dalam beberapa jenis kegiatan upgrade, baik itu upgrade produk atau upgrade fungsional. Sebagian besar petani yang memperbaiki proses produksi mereka dengan mengendalikan kelembaban produk dan peningkatan manajemen pasca panen. Hal ini juga mempengaruhi kesadaran mereka akan standar produksi pasar kopi yang membedakan tiap-tiap standar kelas kopi. Namun masih terdapat hal yang belum dapat dilihat terkait keberlanjutannya dan keuntungan jangka panjang yang dihasilkan. Dalam rantai nilai kopi, pasar membayar sampai dua kali lipat per kantong kopi. Selanjutnya, melalui lelang internet dan membeli langsung, peran perantara lebih kecil dan ini menjamin bahwa harga yang lebih tinggi akan dibayarkan kepada produsen.

Penelitian ini dilaksanakan di Desa Medono Kecamatan Boja Kabupaten Kendal. Pendekatan penelitian yang digunakan ialah kualitatif yang akan memberikan gambaran secara holistik dan mendalam tentang jaringan dan sistem distribusi komoditas lokal. Penelitian ini juga menggunakan data kuantitatif yang dianggap berguna dan relevan dengan pokok penelitian. Adapun sasaran penelitian yang dijadikan subjek dalam penelitian ini adalah masyarakat di Desa Medono Kecamatan Boja Kabupaten Kendal khsususnya bagi orang-orang yang memiliki lahan yang dimanfaatkan untuk menanam tumbuhan komoditas. Untuk tambahan data, dalam penelitian ini ditetapkan beberapa individu sebagai informan pendukung, yaitu: tokoh masyarakat, petani atau pengelola kebun lahan kering, aparat desa, dusun dan kecamatan, dan masyarakat yang berdaim di sekitar lokasi penelitian. Data dikumpulkan melalui in-depth interview, participant observation dan documentation (Moleong 1991). Dalam studi ini menggunakan analisis deskriptif kualitatif. Setelah data yang didapatkan dalam proses penelitian terkumpul dipilih dan dikelompokkan ke dalam pokok penelitian dan disesuaikan dengan tema pokok. Hasilnya dituliskan secara naratif. Data dideskripsikan dan berikan pemaknaan dengan menggunakan interpretasi logis. Keterhubungan antara data, deskripsi dan interpretasi tersebut akan mendapatkan kesimpulan yang benar.

\section{Seting Geografis dan Sosial Desa Medono}

Desa Medono merupakan desa yang berada di kawasan lereng barat Pegunungan Ungaran. Secara administratif Desa Medono berada di wilayah administratif kecamatan Kecamatan Boja, Kabupaten Kendal, Jawa Tengah. Secara administratif dibagi ke dalam dua dusun, tiga RW, dan 6 RT. Jumlah penduduk sebanyak jumlah 906, yang terdiri dari penduduk laki- 
laki 447 jiwa, perempuan 459 jiwa. Luas wilayah Desa Medono 2,2 km2 dengan kontur perbukitan sehingga lahan pemukiman serta lahan untuk pertanian dan perkebunan berada pada lahan dengan kemiringan antara 20 hingga 60 derajat.

Selain untuk pemukiman, lahan dimanfaatkan untuk pertanian dan perkebunan. Lahan untuk pertanian dibedakan menjadi beberapa kategori, yaitu lahan sawah dengan irigasi sederhana, seluas 39 ha, dan lahan tadah hujan 4 ha. Lahan sawah ditanami dengan tanaman pangan terutama tanaman padi, jagung dan sayuran. Lahan sawah dengan irigasi sederhana dapat mengahasilkan panen sebanyak 3 kali yaitu dua kali panen padi, dan satu kali panen sayuran. Sedangkan pada sawah tadah hujan hanya dapat menghasilkan panen dua kali, berupa panen padi dan palawija.

Selain berupa sawah terdapat lahan yang berupa kebun dengan luas 66,42 ha, hutan rakyat seluas 26,88 ha. dan terdapat kawasan hutan milik Negara seluas 40 ha. Lokasi sawah dan kebun berada jauh dari pemukiman, sehingga dalam perawatan tanaman terkendala dengan kondisi topografinya. Akses jalan menuju ke lahan berupa jalan setapak sehingga menyulitkan ketika harus melakukan pengangkutan sarana yang dibutuhkan untuk perawatan maupun ketika mengangkut hasil panen. Untuk mengatasi kondisi tersebut masyarakat umumnya mengunakan sepeda motor yang digunakan untuk ke kebun.

\section{Pengelolaan Lahan oleh Masyarakat}

Berdasarkan angka luasan pemanfaatan lahan tampak bahwa lahan perkebunan lebih luas dibandingkan dengan lahan sawah sehingga potensi untuk produksi tanaman perkebunan lebih tinggi. Lahan perkebunan dimanfaatkan untuk menanam kopi, dan aren. Status lahan perkebunan merupakan lahan milik perorangan. Adapun pengelolaanya ada yang dikerjakan sendiri oleh pemilik lahan, ada juga yang digarap melalui sistem bagi hasil dan sistem sewa tahunan.

Jenis tanaman yang ditanam di kebun disesuaikan dengan kondisi letak dan kemiringan lahan. Pada lahan dengan kemiringan lebih dari 45 derajat dimanfaatkan dengan ditanami pohon kayu seperti sengon dan aren. Kedua jenis tanaman ini lazim ditemui karena tidak membutuhkan banyak perawatan. Bahkan pohon aren ini tumbuh alami, tanpa ditanam oleh warga. Sedangkan pada lahan dengan kemiringan lebih landai ditanami dengan tanaman kopi dan cengkeh. Salah satu alasannya adalah mempermudah proses pemanenan.

Saat ini lahan perkebunan banyak dimanfaatkan untuk tanaman kopi. Jenis kopi yang banyak ditanam adalah kopi robusta. Masyarakat mulai banyak menanam kopi baru sekitar tiga sampai empat tahun belakangan ini. Sebelumnya kopi sudah ada yang menanam tetapi jumlahnya hanya sedikit dan produktivitasnya juga rendah. Kopi yang ada saat ini merupakan kopi yang sudah diremajakan. Peremajaan itu dilakukan setelah adanya pengalaman dan proses belajar dengan petani kopi dari Temanggung. Di Temanggung hasil kopinya lebih baik, sedangkan di Desa Medono masih sangat kurang. Maka kemudian warga mulai berinisiatif untuk meremajakan tanam- 
an kopi dengan jenis kopi yang lebih produktif. Awalnya jenis tanaman kopi yang ditanam di Desa Medono adalah jenis pohon yang tumbuh tinggi, sehingga menyulitkan saat panen. Sedangkan tanaman kopi yang ditanam saat ini adalah jenis kopi yang lebih pendek, sehingga memudahkan pemanenan. Masyarakat mengembangkan bibit kopi secara perorangan, sesuai dengan kemampuan masingmasing. Ada yang membeli bibit dari kebunkebun bibit. Ada juga yang mengembangkan dengan cara menyambung tanaman kopi lama dengan jenis kopi yang sudah diketahui hasilnya baik. Perhatian dari dari dinas atau lembaga terkait dalam bentuk pendampingan, penyuluhan atau bantuan nyaris tidak ada. Bantuan bibit kopi yang pernah diberikan pemerintah ternyata hasilnya kurang bagus dan mengecewakan masyarakat. Waktu tunggu hingga panen hingga dua tahun tetapi hasilnya jelek.

Masyarakat menanam kopi di lahan berdasarkan pengalaman praktek langsung menanam kopi tanpa mengikuti aturan tertentu, tanpa mengikuti aturan jarak tanam atau persiapan pembuatan lubang. Bibit kopi ditanam berdasarkan perkiraan saja menyesuaikan kontur lahan dan kerapatan tanaman. Bahkan dalam satu lahan terdapat berbagai jenis tanaman seperti kopi, cengkeh, pisang, sengon, dan aren. Selama masih ada sela dan tanah rata untuk ditanami maka bibit akan ditanam di tempat tersebut.

Selain tanaman kopi, masyarakat juga mengenal jenis tanaman komoditas lain yaitu cengkeh. Sebelum masyarakat banyak menanam kopi seperti saat ini masyarakat me- nanam cengkeh. Namun karena harga cengkeh di pasaran jatuh, kemudian cengkeh dibabat. Baru sekitar dua tahun belakangan ini masyarakat kembali menanam cengkeh, karena harga cengkeh mulai meningkat.

\section{Kopi dan Aren Sebagai Komoditas Utama}

Kopi dan aren merupakan komoditas utama bagi masyarakat Desa Medono saat ini. Setiap rumah tangga memiliki kebun kopi dengan luasan bervariasi. Tanaman kopi yang ditanam tampak tumbuh dengan baik. Perawatan kebun kopi juga tidak serumit pada tanaman pangan.

Tanaman kopi mulai berbunga pada umur tiga tahun. Namun produktivitasnya mulai optimal pada umur lima tahun. Waktu tunggu berbuah rata-rata enam bulan, sehingga dalam satu tahun kopi hanya berbuah satu kali. Waktu tunggu panen yang cukup lama jika dibandingkan dengan masa panen sehingga ketika sudah mulai berbuah, petani buru-buru memanen kopi padahal biji kopi belum masak karena segera ingin mendapatkan hasilnya. Selain itu juga ingin cepat selesai dalam memanen, misalnya dalam satu tangkai hanya terdapat 10 biji yang sudah masak tetapi seluruhnya dipetik termasuk yang masih muda. Akibatnya hasil panen kopi harganya murah yaitu berkisar Rp 22.000,-/kg kondisi kering. Padahal untuk biji yang sudah tua harganya mencapai Rp 35.000,-/kg kondisi kering.

Intensitas sumber tenaga kerja yang tinggi terjadi pada saat awal penanaman dan pemanenan serta proses pasca panen. Pada saat awal penananam membutuhkan tenaga kerja 
yang banyak untuk pembersihan lahan dan penanaman. Ketika masuk masa perawatan rutin, intensitas kebutuhan tenaga kerja tidak lagi tinggi. Intensitas kebutuhan tenaga kerja akan kembali meningkat saat panen.

Sumber tenaga kerja untuk perawatan dan pemanenan kopi berasal dari luar desa yaitu dari Desa Sukorejo. Upah tenaga kerja ratarata $\mathrm{Rp} 70.000$,- per hari. Namun kadang kala pekerjaan diselesaikan dengan sistem borongan. Pada saat panen, tenaga kerja dihitung berdasarkan berat yang berhasil dipetik Upah tenaga petik kopi disesuaikan dengan lokasi kebun. Jika lokasinya sulit dan jauh, upahnya mencapai Rp 1.500,-/kg. Namun jika lokasinya dekat upahnya hanya Rp1.000,-/kg. Upah itu sudah termasuk upah angkut hingga ke rumah pemilik kebun.

Kendala yang dihadapi dalam perawatan berupa serangan hama yang berupa semut gramang. Semut tersebut membuat sarang pada daun sehingga daun menjadi kering karena terkena kotoran semut. Selain itu, semut juga membuat lubang di sekitar akar pohon sehingga tanah menjadi berongga. Akibatnya pertumbuhan akan tidak optimal sehingga pohonnya mati. Hama lain yang menyerang tanaman kopi adalah penggerek batang dan buah. Batang tanaman kopi akan menjadi kering dan patah sehingga lama-lama mati. Untuk mengatisipasinya masyarakat menggunakan insektisida kimia yang biasa digunakan untuk membasmi hama tanaman padi. Namun upaya pembasmian itu mengalami kendala karena harus mengangkut air untuk menyemprot tanaman kopi yang berada di lereng gunung.
Gula aren termasuk komoditas utama di Desa Medono setelah hasil dari perkebunan kopi. Aren tumbuh liar di kebun tanpa ada penanaman dan perawatan. Pohon aren tumbuh sendiri dari biji yang jatuh ke tanah sehingga dalam satu lahan tidak dapat ditentukan seberapa banyak pohon arean yang tumbuh. Pemilik lahan juga tidak melakukan budidaya aren sehingga mereka hanya mengambil langsung dari alam. Aren mulai berbuah dan dapat menghasilkan nira setelah pohon berumur 10-15 tahun. Setelah dideres maka lama-kelamaan akan kering dan mati. Produktivitas pohon aren tidak dapat ditentukan. Ada kalanya aren tumbuh bunga yang banyak namun ada kalanya hanya sedikit. Jika bunganya banyak maka dapat dideres dan menghasilkan nira yang banyak. Rata-rata satu pohon aren dapat dideres dua sampai tiga bulan.

Untuk mendapatkan nira, aren harus dideres setiap hari. Pada pagi hari penderes memasang jerigen untuk menampung hasil deresan, kemudian pada sore harinya jirigen berisi nira diambil kemudian diproses menjadi

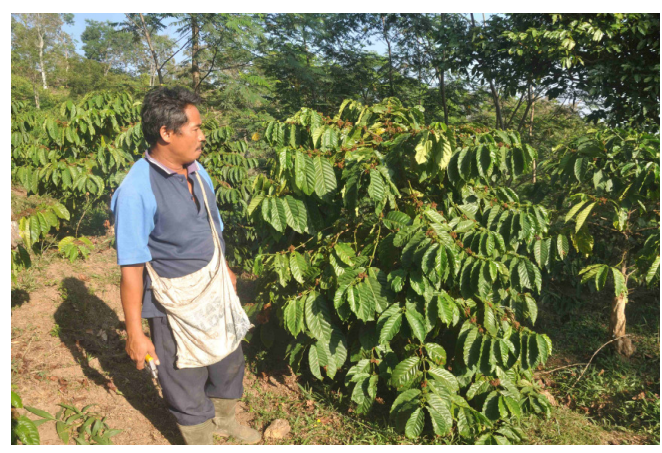

Gambar 1.

Pekebun kopi sedang melakukan perawatan tanaman kopi. 
gula. Untuk tenaga penderes dapat diperoleh melalui beberapa cara. Pertama, pemilik pohon menderes sediri pohon nira miliknya kemudian memrosesnya menjadi gula. Sumber kedua dengan cara bagi hasil. Pemilik pohon aren menyuruh orang lain yang biasa menderes dan membuat gula aren lalu hasilnya dibagi dua. Pembagian tersebut berdasarkan pada harian. Misalnya hasil yang didapatkan pada hari ini menjadi bagian orang yang mengerjakan maka pada hari berikutnya menjadi bagian pemilik pohon.

Bagi masyarakat memiliki pohon aren menjadi jaminan untuk mendapatkan pengha-

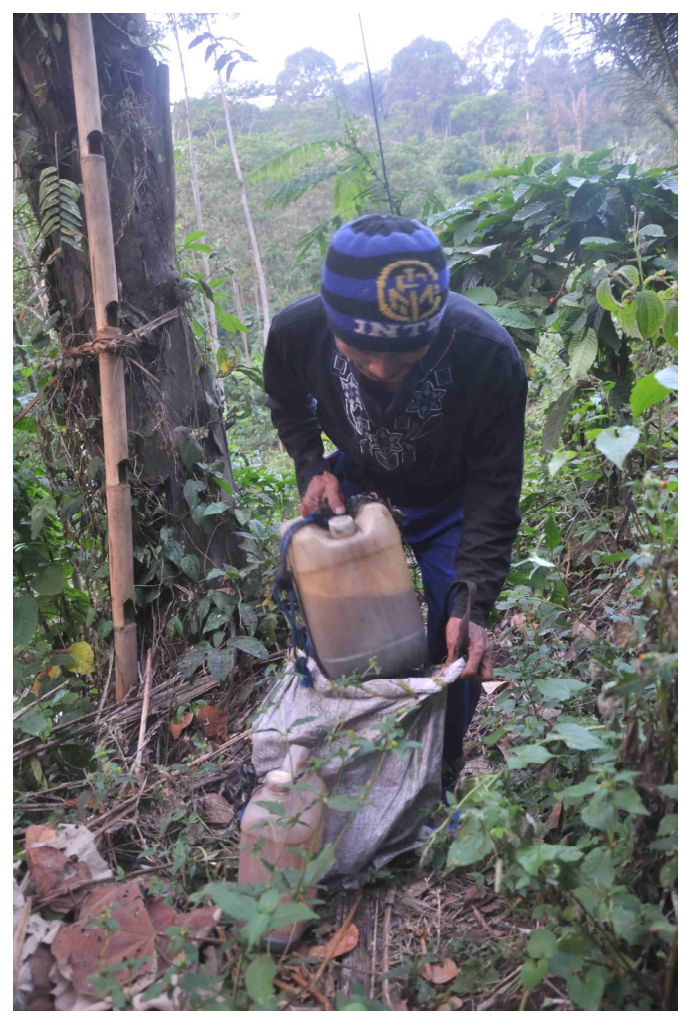

Gambar 2.

Nira hasil deresan yang diambil pada pagi hari. silan harian. Setiap rumah tangga rata-rata memiliki pohon aren antara 10-50 batang pohon. Jika pada jenis tanaman lain membutuhkan waktu tunggu berbulan-bulan untuk mendapatkan hasil, maka aren dapat setiap hari menghasilkan selama masih bisa di deres. Menurut Usman et al. (2014) hasil aren ini memberikan kontribusi untuk memenuhi kebutuhan keluarga petani dalam hal pangan, sandang, tempat tinggal, pendidikan, kesehatan, dan pemenuhan kebutuhan sosial.

Rianse dkk. (2018) juga menegaskan bahwa secara ekonomis pengolahan aren ini memberi peran penting pada tingkat kesejahteraan pengolahnya.

Pemrosesan nira menjadi gula aren dilakukan dengan peralatan sederhana. Nira direbus dengan menggunakan sumber panas dari kayu bakar, kemudian dicetak menggunakan tempurung kelapa.

\section{Distribusi Hasil Kopi dan Aren}

Hasil kopi di Medono didistribusikan keluar desa melalui beberapa jalur distribusi. Petani menjual hasil panen kopi dalam bentuk biji kering. Biji kopi hasil panen dikeringkan dengan cara dijemur di halaman rumah. Proses pengeringan mengalami beberapa kendala, yaitu kondisi musim yang tidak menentu. Proses pengeringan menggantungkan pada sinar matahari, sehingga ketika curah hujan tinggi maka proses pengeringan terganggu. Biji kopi berjamur dan busuk sehingga kualitas dan harganya menurun. Selain itu juga terkendala pada ketersediaan lahan untuk pengeringan. Penjemuran bisanya dilakukan 
di halaman rumah, sedangkan kondisi pemukiman yang padat mengakibatkan terbatasnya tempat untuk menjemur. Karena beberapa kendala tersebut maka sering kali menjual hasil biji kopi dengan kadar air masih tinggi sehingga harganya lebih rendah.

Hasil panen biji kopi dijual ke pengepul yang ada di desa. Jika hasil panen hanya sedikit maka dijual pada warung-warung yang ada di desa lalu dijual ke pasar dalam kondisi biji kopi kupas kering mentah. Di Medono juga terdapat pengepul antara yang menampung panen biji kopi dalam jumlah banyak, kemudian memroses kopi menjadi kopi kering yang sudah dikupas. Kopi tersebut kemudian disetorkan pada pengepul di luar Desa yang sudah menjadi partner dagangnya.

Dalam proses distribusi kopi terdapat hubungan patron-klien antara pengepul antara dengan pengepul yang lebih besar dari luar desa. Melalui hubungan baik dan kepercayaan yang sudah terbentuk, pengepul antara dari Medono biasa meminjam uang sebagai modal terlebih dahulu dari pengepul besar kemudian mengembalikannya dengan menyetorkan kopi yang ditampungnya. Ada juga dengan sistem tunda bayar yaitu pembayaran dilakukan pada saat penyetoran berikutnya.

Distribusi gula aren dilakukan dengan dua jalur. Yang pertama gula aren yang dihasilkan dijual ke warung-warung yang ada di dalam desa. Gula tersebut diperuntukkan untuk memenuhi konsumsi masyarakat di Desa Medono. Sedangkan yang kedua dengan dijual ke pasar. Salah satunya di pasar Gunungpati.

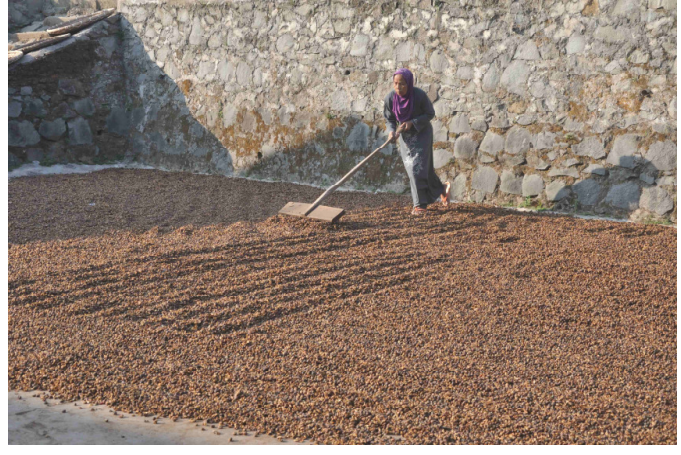

Gambar 3.

Hasil panen kopi sedang dijemur di halaman gudang milik pengepul di Medono

Harga gula Aren di pasaran mencapai Rp 17.000,-/kg. Gula hasil produksi masyarakat Medono harga jualnya cukup tinggi dibanding dari daerah lain karena sudah dikenal sebagai gula aren yang masih murni tanpa diberi tambahan dari bahan lain.

Sebagai salah satu desa di lereng sebelah Barat Gunung Ungaran, Desa Medono memiliki karaktersitik lahan dengan topografi yang tinggi dan sistem pertanian lahan kering. Kopi dan Aren merupakan dua komoditas utama yang diusahakan oleh masyarakat, di samping tanaman holtikultura lainnya yang ditanam secara subsisten. Kedua komoditas ini merupakan tanaman tahunan yang tidak harus ditanam setiap tahun, tetapi hanya dipelihara dan dijaga dari hama penyerang. Jika kopi sengaja diusahakan masyarakat dan menjadi sumber pokok penghasilan mereka, maka aren merupakan tanaman liar yang dibiarkan tumbuh di kebun-kebun mereka dan menjadi sumber pemasukan masyarakat untuk memenuhi kebutuhan pokok harian mereka.

Sistem distribusi kedua komoditas ini memanfaatkan jaringan dari orang lokal sebagai 
pengepul dan orang luar sebagai penadah (penjual dan juragan). Orang lokal adalah masyarakat setempat yang membeli biji kopi dan nira dari masyarakat. Pada komoditas kopi, masyarakat yang menjual kopinya ke pengepul berupa biji kopi yang sudah dijemur, sedangkan komoditas nira dijual setelah nira diolah menjadi gula aren. Pada tahap selanjutnya, pengepul menjual ke penadah yang biasanya merupakan pedagang kopi di Pasar Boja dan gula aren di Pasar Gunungpati. Penadah kopi juga sekaligus menjadi juragan yang kerap memberi pinjaman modal kepada petani dan pengepul kopi. Dengan sistem distribusi seperti ini, petani kopi mengalami kesulitan untuk mematok harga dan berganti pada juragan yang lain. Selain karena adanta keterlekatan ekonomi, faktor sosial berupa ewuh pekewuh pada juragan yang telah meminjamkan modal juga menjadi keterlekatan budaya yang mempenaruhi jaringan distribusi kopi.[]

\section{Daftar Pustaka}

Abdurrahman, A., A. Dariah, dan A. Mulyani. 2008. "Strategi dan Teknologi Pengelolaan Lahan Kering Mendukung Pengadaan Pangan Nasional." Jurnal Litbang Pertanian 27(2):43-49.

Conelly, W. T. dan M. S. Chaiken. 2000. "Intensive Farming, Agro-Diversity, and Food Security Under Conditions of Extreme Population Pressure in Western Kenya." Human Ecology 28(1):19-51.

Eakin, Hallie., C. Tucker, dan E. Castellanos. 2006. "Responding to the Coffee Crisis: a Pilot Study of Farmers' Adaptations in
Mexico, Guatemala and Honduras." The Geographical Journal 127(2):156-71.

Fromm, Ingrid. dan J. A. Dubón. 2006. "Upgrading and the Value Chain Analysis: The Case of Small-scale Coffee Farmers in Honduras." Conference on International Agricultural Research for Development.

Hutterer, Karl Leopold. 1984. "The Natural and Cultural History of Southeast Asian Agriculture: Ecological and Evolutionary Considerations." Anthropos Bd. 78(H. 1./2):169-212.

Kementerian-Pertanian. 2014. Pusat Data dan Sistem Informasi Pertanian. Jakarta: Sekretariat Jenderal - Kementerian Pertanian.

Ladefoged, T., M. Graves, dan R. Jennings. 1996. "Dryland agricultural expansion and intensification in Kohala, Hawai'i Island." Antiquity 70(270):861-80.

Moleong, L. 1991. Metode Penelitian Kualitatif. Bandung: Remaja Risdakarya.

Prasetyo, B. H. dan D. A. Suriadikarta. 2006. "Karakteristik, Potensi, dan Teknologi Pengelolaan Tanah Ultisol untuk Pengembangan Pertanian Kering di Indonesia." Jurnal Litbang Pertanian 25(2).

Ruiter, Tine G. 1999. "Agrarian Transformations in the Uplands of Langkat: Survival of Independent Karo Batak Rubber Smallholders." dalam Transforming the Indonesian Uplands: Marginality, Power and Production, ed. T. M. Li. Amsterdam: Harwood Academic Publishers.

S Rianse, I. et al. 2018. The Income Distribution and Contribution of Palm Sugar Producer in Increasing the Household Welfare of 
palm sugar maker in Kolaka Southeast Sulawesi Indonesia.

Smith, Erin Sue. 2010. “The Evolution Of Coffee Markets For Sustainable Development: A Honduran Cooperative's Experience With Fair Trade." California State University.

Suryanata, Krisnawati. 1999. "From Home Gardens to Fruit Gardens: Resource Stabilisation and Rural Differentiation in Upland Java." dalam Transforming the Indonesian Uplands: Marginality, Power and Production, ed. T. M. Li. Amsterdam: Harwood Academic Publishers.

Syahrizal. 2006. Strategi Buruh Perkebunan Mengatasi Kemiskinan, Studi di Per- kebunan Teh PT Mitra Kerinci Sumatera Barat. Padang: Andalas University Press.

Usman, A., A. Suman, L. Hakim, dan W. Muhaimin. 2014. "The Impact of Home-Based Business Processing Palm Sugar to Increase Socio-Economic Welfare of Farmers in South Halmahera Regency." IOSR: Journal of Business and Management (IOSR-JBM) 16(1):32-37.

White, Ben. 1999. "Nucleus and Plasma: Contract Farming and the Exercise of Power in Upland West Java." dalam Transforming the Indonesian Uplands: Marginality, Power and Production, ed. T. M. Li. Amsterdam: Harwood Academic Publishers. 
This page is intentionally left blank 